\title{
LA IRRUPCIÓN DEL COGITO
}

María Noel Lapoujade*

RESUMEN: A partir de un análisis minucioso de los textos de Descartes, la autora describe e interpreta desde una filosofía de la imaginación, el surgimiento del cogito, desde la voz interior del filósofo, hecha de intuición y entendimiento, sentidos e imágenes, noche y día.

soes

ABSTRACT: Based on a detailed analysis of Descartes' texts and on his philosophy of imagination, the author describes and interprets the emergence of cogito from the philosopher's internal voice, consisting of intuition and understanding, senses and images, and night and day.

PALABRAS CLAVE: Cogito, imaginación, pensamiento, intuición, imagen, entendimiento. KEYWORDS: Cogito, imagination, thought, intuition, image, understanding.

RECEPCIÓN: 11 de noviembre de 2009.

APROBACIÓN: 27 de mayo de 2010.

* Facultad de Filosofía y Letras, UNAM. 
CITAM Derechos Reservados.

La reproducción total o parcial de este artículo se podrá hacer si el ITAM otorga la autorización previamente por escrito. 


\section{LA IRRUPCIÓN DEL COGITO}

...la restitution d'un être pensant uniquement fondée sur l'examen des textes conduit à l'invention de monstres. Paul Valéry. ${ }^{1}$

\section{El propósito de este ensayo es cons-} truir el desarrollo de la lectura del cogito a que el título alude, en el marco de una filosofía de la imaginación como clave para interpretar este tema en el contexto del pensamiento cartesiano, como expresión del Descartes humano, de carne y hueso.

Nombrar una irrupción invoca a nuestro espíritu para estar atento. Estar atento a la aparición repentina de algo que brota con fuerza para hacerse visible $y$, en general, perceptible.

Desde una perspectiva externa, la irrupción del cogito se emplaza en la historia de la filosofía como un momento necesario a la misma. Desde una filosofía de la imaginación, en este caso, una filosofía puesta en imágenes, esta perspectiva externa puede diseñarse esquemáticamente como sigue.

La larguísima y fecunda época medieval, está poblada de muy diversas concepciones del hombre, plasmadas en imágenes del mundo en las que, el hombre en el centro de la creación, abre su ser a la trascendencia, al misterio, a Dios. Esta época, durante siglos, crea imaginarios de todo orden, de un esplendor deslumbrante.

${ }^{1}$ Paul Valéry, Oeuvres Complètes, Paris, Gallimard, 1957, vol. I, Variété, Études philosophiques, p. 817. 
Martín Buber lo resume magistralmente en una imagen: la imagen medieval del mundo:

Es una cruz cuyo madero vertical es el espacio finito entre cielo e infierno, que nos lleva directamente a través del corazón humano, y cuyo travesaño es el tiempo finito desde la creación hasta el día del juicio; su centro, la muerte de Cristo, coincide cubriéndolo y redimiéndolo, con el centro del espacio, el corazón del pobre pecador. ${ }^{2}$

Si continuamos la reflexión con base en la imagen medieval del mundo según Martín Buber, puede sostenerse que el Renacimiento rompe, científicamente, con los límites de la finitud espacio-temporal del mundo, y como bien sostiene Alexander Koyré, el hombre pasa del mundo cerrado al universo infinito. ${ }^{3}$ Más aún, el hombre deviene un punto insignificante, un verdadero grano de polvo, moviéndose en una móvil circunferencia infinita donde el centro está en todas partes y la circunferencia en ninguna. ${ }^{4}$

La humanidad, en sus concepciones, goza de su arte, su ciencia y sus técnicas, y sin embargo, ese mundo nuevo de inabarcables fronteras cósmicas deja resonancias de incertidumbres filosóficas profundas.

10 Engarzada en imágenes puede comprenderse la exclamación algo posterior de Blaise Pascal, quien en nombre de la noción de "junco pensante" (nótese que su tesis filosófica se resume en una imagen), anticipa la angustia existencial del siglo XX, cuando afirma: "el silencio eterno de los espacios infinitos me espanta". 5

La armoniosa música pitagórica de las esferas ha devenido el silencio absoluto de los espacios infinitos, y el hombre, un itinerante punto descentrado. La acogedora morada medieval del mundo, deviene un inatrapable espacio infinito, donde el seguro mundo de esferas fijas deviene un gigantesco y sincronizado aparato móvil.

\footnotetext{
${ }^{2}$ Martin Buber, ¿Qué es el hombre?, 1964, México, FCE, Breviario 10, p. 28.

${ }^{3}$ Alexander Koyré, Del mundo cerrado al universo infinito, 1979, México, Siglo XXI.

${ }^{4}$ Nicolás de Cusa, La docta ignorancia, 1961, Buenos Aires, Aguilar.

${ }^{5}$ Blaise Pascal, Pensées, 1928, (1670) París, Librairie Aristide Quillet, 70, p. 23.
} 
Ante la complejidad desconcertante del mundo nuevo, la especie humana, desorientada, se repliega filosóficamente sobre sí misma. La filosofía se vuelve introvertida. Recogida en el centro del alma, busca el pilar sólido y seguro del cual partir.

En los inicios del siglo XVII, a partir de 1605, esa "rara avis" en la historia de la filosofía, que se llama Francis Bacon, humanista, científico, epistemólogo, pedagogo, utopista, poeta en prosa, un sabio en fin, presenta su filosofía en un enjambre de metáforas precisas, rigurosas y bellas. Vuelve una vez más su mirada escrutadora hacia aquel "huerto del alma" del que un siglo antes habló Teresa de Ávila, y se encuentra con un selvático mundo interior. Antes de cultivar, es preciso desbrozar el terreno; así construye su teoría de los ídolos, para limpiar y allanar el terreno. De este modo, Bacon pretende purificar la mente de un conjunto de errores, falsos conceptos etc. ${ }^{6}$ En tal sentido, para limpiar el terreno, dedica una buena parte de su obra a realizar, una suerte de minuciosa "fenomenología" no ya "del espíritu", sino de la mente, de la subjetividad humana integrada fundamentalmente por sensibilidad, imaginación, entendimiento, voluntad, afectividad. Se preocupa de observar, describir y señalar, para corregir, el que llama el "cambiante espejo de la mente". ${ }^{7}$ Dice Bacon:

La mente del hombre está lejos de ser de la naturaleza de un claro y límpido espejo en el cual la forma de las cosas se refleja de acuerdo con su verdadera incidencia; por el contrario, es más bien semejante a un espejo encantado, lleno de supersticiones e imposturas, a menos de verse liberada y redimida de ellas. ${ }^{8}$

Por su parte, René Descartes, a partir de 1628, después de Bacon (entre 1605 y 1620) con quien las afinidades filosóficas son profundas,

${ }^{6}$ María Noel Lapoujade, Los sistemas de Bacon y Descartes. De la coincidencia de los opuestos, 2002, México, Facultad de Filosofía y Letras, Benemérita Universidad Autónoma de Puebla.

${ }^{7}$ Francis Bacon, Del adelanto y progreso de las ciencias, (1605), 1984, México, Juan Pablos Editor, 1984, p. 133.

${ }^{8}$ Idem, p. 266. 
emprende un camino similar. Ciertamente, las diferencias, que no oposiciones, en su mayoría no son más que el resultado de lecturas distorsionadas por la rigidez de los esquemas hermenéuticos de la crítica. ${ }^{9} \mathrm{La}$ catarsis baconiana de los ídolos, encuentra su partenaire en la purificación cartesiana de la duda, que en nuestro autor es una ficción, es decir, imaginaria, hiperbólica y voluntaria. Despejado el terreno de la subjetividad de las malezas invasoras, el filósofo se yergue sobre sí mismo y aguza su mirada hacia su propio espíritu.

En suma, ante la inextricable complejidad del mundo nuevo surgido del Renacimiento, el filósofo busca cobijo; y su único refugio seguro es la caverna inexpugnable del cogito.

Desde una perspectiva interna, esto es, desde el pensamiento cartesiano mismo.

Considero que los estudios de Paul Valéry sobre René Descartes constituyen una referencia imprescindible para abordar el pensamiento cartesiano. En los pasajes en que Paul Valéry escruta atentamente el proceso espiritual del nacimiento del sistema cartesiano, nuestra perspectiva se encuentra con el punto de vista del exégeta, tal como en este bello y preciso pasaje:

Descartes nos comunica su vida, a fin de que la serie de sus impresiones y sus actos nos introduzca en sus pensamientos por el mismo camino natural de acontecimientos y sueños que él había vivido desde la juventud [...]

¡Qué lujo de libertad, qué elegante y voluptuoso modo de ser él mismo, cuando el hombre puede disiparse de tal manera entre las cosas, sin dejar de confirmarse en sus ideas! ${ }^{10}$

En la vida del Descartes de carne y hueso, la irrupción del cogito brota necesariamente en medio de la intensa búsqueda espiritual de un ser humano excepcional, integral, total. Esta descubierta filosófica que significa un viraje radical para toda la historia de la filosofía occi-

\footnotetext{
${ }^{9}$ He desarrollado este tema en Los sistemas de Bacon y Descartes. op . cit.

${ }^{10}$ Paul Valéry, Oeuvres Complètes, 1957, Paris, Gallimard, vol. I, Fragment d'un Descartes, Etudes Philosophiques, Variété, p. 790.
} 
dental, no es la inferencia lógica de un proceso de reflexión filosófica pura, ni es la consecuencia del ejercicio de la actividad filosófica de un filósofo de gabinete.

En medio de un vital "movimiento en torbellino", en días previos de agitación, de oscuridad, de no ver nada, de ojos ciegos para su espíritu en turbulenta concentración; en esos momentos, el espíritu se prepara en un estado de disponibilidad, de receptividad, colmado por los rayos luminosos de las impresiones oníricas y visionarias. ${ }^{11}$

En este contexto irrumpe el camino conducente a su meta, la verdad. Uso muy deliberadamente el verbo "irrumpir", pues el acto de la evidencia, de ver claro y necesariamente en el fondo de sí mismo, es el instante fugaz, tiempo sin duración, en que emerge bruscamente la luz que iluminará su vida y la de muchas generaciones pensantes futuras. El cogito, formulado claramente en el siglo IV por San Agustín, recobra el aliento y con René Descartes se transmuta en el faro que señala el comienzo y la vía de toda filosofía radical orientada hacia la vida. ${ }^{12}$

Descartes introspectivo, evitando "la precipitación y la prevención", se sumerge voluntariamente en la acción imaginaria de una duda en la que no se engaña; una duda que sabe imaginaria, la ficción de una duda universal. El cogito brota a su espíritu puro y atento, como una luz en la oscuridad, como una visión clara y distinta resultante de un acto de intuición. ${ }^{13}$

Intuir significa ver. Con apego al sentido etimológico, Descartes establece que: "la manera como hace falta utilizar la intuición nos es conocida por comparación con la vista". ${ }^{14}$

En tal sentido, se constata que el ojo no puede ver, distinguir, varios objetos a la vez en una sola mirada, en tanto que el ojo, educado de

${ }^{11}$ Cita de la Vie de M. Descartes por Baillet, 1691, Paris, citado por Paul Valéry, op. cit., Une vue de Descartes, Etudes Philosophiques, en Variété, p. 814.

${ }^{12}$ Analicé minuciosamente el tema en Los sistemas de Bacon y Descartes... pp. 57-93.

13 "Par intuition j'entends, non pas le témoignage changeant des sens ou le jugement trompeur d'une imagination qui compose mal son objet, mais la conception d'un esprit pur et attentif, conception si facile et si distincte qu'aucun doute ne reste sur ce que nous comprenons." Descartes, Oeuvres et Lettres, 1953, Paris, Gallimard, Règles pour la direction de l'esprit, Règle III, pp. 43-5. Cfr., M.N. Lapoujade, Los sistemas..., op. cit., p. 203 ss.

${ }^{14}$ R. Descartes, op. cit., Règle IX., p. 67-68. 
los artesanos que se ocupan de trabajos delicados, acostumbra dirigir atentamente su mirada sobre cada punto preciso. Así adquiere, por el uso, la habilidad para distinguir, aún las cosas más pequeñas y finas. Así, el espíritu por intuición debe dirigirse de manera inmediata y certera a pocos asuntos "simples y fáciles".

El método y el ejercicio, es decir, la práctica, educan el espíritu para, expresado en una célebre metáfora, ver de manera clara y distinta. Sumido en las tinieblas de la duda provocada, de la ceguera metódica, se recorta a su mirada espiritual un punto claro y distinto: el cogito, comprendido "todo entero y al mismo tiempo y no sucesivamente". El cogito, parafraseando a Bachelard, es el fruto exquisito de "la intuición del instante".

En las profundidades de su propio hacer como si todo fuera falso, con el que anticipa al radical como si kantiano, Descartes, explorador minucioso, se topa con un hallazgo asombroso en su propio espíritu, el de la certidumbre luminosa del cogito, pilar firme del cual, en cascada, derivan certezas hasta alcanzar la certidumbre de Dios.

En este sentido, Edgar Morin señala al cogito como dínamo, como generador:

Así, el cogito es un bucle generador, formador, transformador, productor y no una verificación (tauto) lógica o una prueba ontológica. ${ }^{15}$

La vía epistémica, vía de conocimiento (ordo cognoscendi) avanza vertiginosamente en un camino regresivo:

Dudo---Pienso---Soy---Dios es.

La vía ontológica, vía de fundamentación (ordo essendi) nos devuelve al punto de partida en sólo tres pasos de ligera agilidad:

Dios es---Soy---Pienso---Dudo.

${ }^{15}$ Edgar Morin, La Méthode. Tome II, La Vie de la Vie, 1980, Paris, Editions du Seuil, Points, Essais, Deuxième Partie, 4, IV, A, Le cogito, p. 180. 
La elegancia de este movimiento de elasticidad felina expresa una conquista humana radical. ${ }^{16}$

\section{¿Qué significa pensar para Descartes?}

La vivencia inmediata del cogito la ve integrada en el tejido viviente del espíritu. Después de haber vivido la experiencia del pensar, Descartes narra la connmoción vivida en múltiples relatos autobiográficos, sus obras, en las que la experiencia originaria deviene metateoría del pensar. En las Respuestas a las Quintas Objeciones de Gassendi, Descartes señala el equívoco que envuelve la palabra alma, cuando se toma indistintamente por espíritu. Con el propósito de evitar la ambigüedad, nuestro filósofo propone el nombre de espíritu para denotar "el principio por el cual pensamos". En tal sentido, precisa Descartes, "no considero el espíritu como una parte del alma, sino como esta alma toda entera que piensa". ${ }^{17}$

Su vivencia es la de un pensar que irrumpe como una fuerza que brota, que se hace espontáneamente, se realiza en nosotros, somos una totalidad pensante que de manera natural conceptúa, juzga, razona, imagina, recuerda, quiere y siente. ${ }^{18}$ Descartes despliega su concepción del espíritu sano como las actividades integradas de la sensibilidad, la imaginación, el entendimiento, la memoria y la voluntad. En la Regla XII es terminante:

Así pues, hace falta sevirse de todos los auxilios que sea posible, del entendimiento, de la imaginación, de los sentidos y la memoria, sea para tener la intuición clara de proposiciones simples, sea para comparar las cosas buscadas con las conocidas a fin de descubrirlas, sea para encon-

${ }^{16}$ Op. cit., cap. I, El cogito, pp. 57-93.

${ }^{17}$ René Descartes, Oeuvres et Lettres, 1953, Paris, Gallimard. Réponses de l'Auteur aux Cinquièmes Objections faites par Monsieur Gassendi, Cinquièmes Réponses, Des choses qui ont été objectées contre la Seconde Méditation, p. 482. Cfr. además, Lettre à Mersenne, Leyde, 27 avril 1637, donde Descartes afirma que: "vouloir, entendre, imaginer, sentir, etc., ne sont que des diverses façons de penser, qui apartiennent toutes à l'âme", Oeuvres Complètes, p. 963.

${ }^{18}$ Concepción a la que hice referencia en Los sistemas de Bacon y Descartes, p. 89. 
trar las cosas que deben ser comparadas entre ellas, de suerte tal que no se olvide ningún medio a disposición del poder del hombre. ${ }^{19}$

\section{Teoría cartesiana de la imaginación}

La imaginación desempeña un papel central en el pensamiento cartesiano porque interviene en un conjunto complejo de operaciones del espíritu. Descartes establece, avant la lettre, una teoría de la imaginación extendida a lo largo de toda su obra. ${ }^{20} \mathrm{La}$ imaginación es la fuerza que produce las figuras, las imágenes, implicadas en todo objeto sensible. Ella configura, representa figurativamente, es decir, de manera sensible. Imaginar es el trabajo con "imágenes pintadas en la imaginación". ${ }^{21}$

Descartes distingue: por un lado, la posibilidad de imaginar cuerpos. En este sentido, la imaginación transmuta la imagen sensorial del cuerpo en figura, silueta, cuadro mental.

En este sentido primordial, las Meditaciones enuncian: "imaginar no es otra cosa que contemplar la figura o la imagen de una cosa corporal". ${ }^{22}$ Es lo que en un lenguaje clásico se llama, sostengo que impropiamente, "imaginación reproductora". He desarrollado el argumento en Filosofía de la imaginación. ${ }^{23}$

Por otro lado, tomo por ejemplo un pasaje de Las pasiones del alma, donde Descartes describe las funciones del alma, entre ellas la voluntad, la percepción, la imaginación. En este contexto expone su concepto de lo que, tradicionalmente, de manera simplista, se reconoce como "imagi-

${ }^{19}$ René Descartes, Oeuvres et Lettres, Règles pour la direction de l'esprit, Règle XII, p. 75.

${ }^{20}$ Dados los límites de este ensayo, sólo hago énfasis en los temas centrales de la teoría cartesiana de la imaginación, que he investigado in extenso en libro aún inédito.

${ }^{21}$ Descartes, op. cit., Règle XIV.

${ }^{22}$ Descartes, op. cit, Méditations.

${ }^{23}$ M.N.Lapoujade, Filosofía de la imaginación, 1988, México, Editorial Siglo XXI, cap. 2, II: Una fenomenología de la imaginación; I: Imaginación y percepción, pp. 109-12; II; cfr. la crítica a la teoría de imaginación de Jean-Paul Sartre, pp. 120-31. Todo lo cual se resume en la conclusión: "la imagen exhibe una sobreabundancia esencial respecto del percepto", p. 131. 
nación creadora", término que usaremos por mor de la brevedad. ${ }^{24}$ Allí leemos:

Cuando nuestra alma se pone a imaginar cualquier cosa que no existe, como representarse un palacio encantado o una quimera, o cuando se pone a considerar cualquier cosa que sólo es inteligible pero no imaginable, por ejemplo su propia naturaleza, las percepciones que tiene de dichas cosas dependen principalmente de la voluntad, que hace que las pueda percibir; por ello, se acostumbra considerarlas más como acciones que como pasiones. ${ }^{25}$

Respecto de este pasaje es preciso enfatizar dos notas. Primero, Descartes reconoce la capacidad de la imaginación de darse sus propios objetos, sus imágenes fantásticas, que no caen bajo los sentidos, es decir, de crear sus imágenes. Asimismo, reconoce la imaginación creadora como ligada a la voluntad. Si y cuándo el sujeto "quiere", "decide", entonces puede crear imágenes nuevas. En tal sentido, reconoce que la imaginación en sus facetas creadoras es voluntaria, y por ende, acción y no pasión.

Considero importante ampliar esta reflexión más allá de la propuesta cartesiana para dar cuenta de la complejidad y actualidad de los problemas implícitos en estas líneas del pasaje citado. Es preciso tomar conciencia de la inmensa problemática de los mundos de la imaginación creadora no voluntaria. Efectivamente, sí es posible crear imágenes no miméticas del objeto sensible, las llamadas imágenes nuevas, de manera voluntaria, deliberadamente. Pero no se agota en ello esta posibilidad de la imaginación humana. En particular, respecto del texto cartesiano, es preciso añadir las pasiones despertadas, alimentadas y aún exacerbadas por imágenes sustitutivas del objeto, presentes en su ausencia (siguiendo por comodidad el lenguaje tradicional: reproductoras) o imágenes fantaseadoras, que intensifican las pasiones, que pueden continuar llamándose creadoras, para una rápida comunicación.

${ }^{24}$ Idem.

${ }^{25}$ Descartes, op. cit., Les passions de l'âme, Art. 20, p. 705. 
Pero además, en general, la libertad de la ensoñación, en la lógica onírica y en las diversas patologías de la imaginación; allí la imaginación segrega, en general, imágenes no deliberadas, y en la patología, en un primer sentido, no deseadas. Piénsese entre otras, en las alucinaciones, entre las imágenes "sufridas", imágenes que brotan perturbadoras, que interrumpen la armonía y la serenidad del psiquismo.

Finalmente, en el ámbito de la creación artística, no todos los artistas crean mediante el pensamiento lúcido; sabemos también de la creación como el surgimiento necesario, que se antepone al artista, de una obra o aspectos de la misma en la forma de imágenes mentales anticipatorias del objeto.

Segundo, el pasaje que estamos analizando contiene, además, la respuesta cartesiana a otro problema muy complejo y actual. Se trata de la polémica en torno a las relaciones entre imagen y concepto, entre imaginación y entendimiento.

\section{Imaginación y entendimiento}

Este tema es retomado y respondido en múltiples y reiteradas ocasiones a lo largo de toda la obra de nuestro pensador. Considero que el planteamiento del problema y su respuesta adquiere sentido filosófico profundo en el marco de la postura crítica, como un aspecto de ella. La filosofía crítica planteada teóricamente como tal, tiene a Kant como portavoz indiscutible. Sin embargo, como lo he desarrollado en Los sistemas de Bacon y Descartes y en Filosofia de la imaginación, esta postura encuentra sus claros antecedentes filosóficos en Bacon y Descartes. ${ }^{26}$

Baste aquí solamente su mención, como delimitación del terreno en que se ubica el problema general de la pregunta por la relación de la imagen con el pensamiento y sus funciones secretoras: la imaginación y el entendimiento.

${ }^{26}$ M.N. Lapoujade, Los sistemas de Bacon y Descartes..., cap. II: La crítica y el método, pp. 129-70. Filosofía de la imaginación, Cap. 1, III: La imaginación y la incipiente actitud crítica, pp.42-55, especialmente pp. 51-5. 
Descartes, en la Regla VIII, afirma que el primer problema a plantear es precisamente el de "los límites del espíritu", o "los límites de la inteligencia humana”. Una cita, elocuente por sí misma:

Ahora bien, no hay nada más útil aquí que buscar qué es el conocimiento humano y hasta dónde se extiende.

Por ello ahora reunimos estos problemas en una sola pregunta, y estimamos que ésta debe ser examinada la primera de todas a partir de las reglas enunciadas anteriormente; es lo que debe hacer una vez en la vida cualquiera que ame un poco la verdad [...] Al contrario, nada me resulta más absurdo que discutir atrevidamente sobre los misterios de la naturaleza, sobre la influencia del cielo en nuestra tierra y sobre la predicción del futuro y otras cosas semejantes, como hace tanta gente, y de no haber buscado jamás, sin embargo, si la razón humana es capaz de descubrir tales $\operatorname{cosas}^{27}$

En este contexto, voy a partir de un par de nociones obvias, de entendimiento e imaginación. El entendimiento entiende, piensa; es decir, conceptúa, juzga, reflexiona; busca aprehender y comprender reflexivamente (entender). La imaginación imagina, es decir, segrega imágenes, configuraciones, figuras, siluetas mentales de los objetos reales o ficticios, presentes o ausentes, presentes, pasados, futuros o utópicos, etc. A partir de allí, ambos van tejiendo actividades de menor o mayor complejidad, hasta las más complejas actividades del espíritu humano. ${ }^{28}$ De estas definiciones básicamente claras surge un problema profundamente complejo:

\section{¿Es posible el pensamiento sin imágenes?}

Históricamente el debate ha arrojado diversas perspectivas entre los goznes de dos posturas extremas: las respuestas afirmativas y las negativas. Descartes es claro, terminante y consecuente en su respuesta afirmativa radical. Asume una respuesta afirmativa radical: es posible el pensa-

${ }^{27}$ Descartes, Règle VIII, p. 65.

${ }^{28}$ Remito al lector una vez más a mis libros y artículos, de una filosofía que vengo desarrollando desde los 80'. 
miento sin imágenes. Los pasajes expositivos son claros y reiterados. En Los principios afirma:

La imaginación, el sentimiento y la voluntad dependen a tal grado de una cosa que piensa que no los podemos concebir sin ella. Pero, al contrario, podemos concebir el entendimiento sin figura y sin movimiento, y la cosa que piensa sin imaginación o sin sentimiento, y así lo demás. ${ }^{29}$

Una argumentación retomada por nuestro filósofo en múltiples ocasiones es la que se basa en la consideración de la "figura" de un chiliogone, es decir, la "figura" geométrica de mil lados.

Las comillas, claro está, obedecen a la concepción cartesiana de la imposibilidad de componer imaginariamente una figura de mil lados. ${ }^{30}$

Descartes distingue claramente la función del entendimiento, en cuanto intelección o concepción pura; respecto de la función de la imaginación, en cuanto creadora de "cuadros" mentales, de figuras, o por así decir, es la diseñadora de siluetas. En tal sentido, según Descartes el movimiento del entendimiento es hacia el espíritu, en tanto que el movimiento de la imaginación se engarza al cuerpo:

Insisto [...] en que esta virtud de imaginar que está en mí [...] difiere del poder de concebir [...] esta manera de pensar difiere solamente de la intelección pura en que el espíritu al concebir, se vuelve de alguna manera hacia sí mismo [...] pero, al imaginar, se vuelve hacia el cuerpo, y considera cualquier cosa conforme a la idea que ha formado de sí mismo o que ha recibido de los sentidos. ${ }^{31}$

En suma, el cogito irrumpe en el espíritu, en la intuición de un instante, sin imágenes. ${ }^{32}$ En su carta a Elisabeth, de 1643, Descartes propone

${ }^{29}$ Descartes, op. cit., Les principes de la Philosophie, Première Partie, 53, p. 595. Las itálicas son propias.

${ }^{30}$ En este punto de la reflexión, en torno al argumento del chiliogone sigo la Méditation Sixième. Cfr. además, Réponses aux Premières Objection, de Caterus, p. 353.

${ }^{31}$ Descartes, op. cit., Méditations, Méditation Sixième, p. 319.

${ }^{32} \mathrm{Cfr}$. las citas correspondientes a las notas 24 y 28 . 
una formulación extremadamente clara y precisa del papel del entendimiento, la imaginación y los sentidos, cuando afirma:

Primeramente, pues, establezco una gran diferencia entre estas tres especies de nociones en que el alma no concibe más que por medio del entendimiento puro; el cuerpo, es decir la extensión, las figuras y sus movimientos, pueden conocerse sólo por el entendimiento, pero mejor por el entendimiento ayudado por la imaginación; y, en fin, las cosas que pertenecen a la unión del alma y el cuerpo no se conocen más que oscuramente por el entendimiento solo, ni por el entendimiento ayudado por la imaginación; pero se conocen muy claramente por los sentidos. ${ }^{33}$

El pensar puede aprehenderse por el entendimiento puro, puede conocerse por pura intuición, pero de ahí no se infiere que se pueda prescindir de la imaginación, porque ella es necesariamente inherente al espíritu y, por ende, es esencial a la naturaleza humana como tal.

Aquello que he dicho acerca de la imaginación es muy claro [...] son dos cosas enteramente diferentes, pertenecer a mi esencia y pertenecer al conocimiento que tengo de mí mismo. ${ }^{34}$

En síntesis, en Descartes la imaginación es esencial a lo humano. ${ }^{35}$ Dos consideraciones para concluir este parágrafo.

Primero, coincido con la concepción cartesiana de la imaginación en cuanto esencial a lo humano. Sin embargo, difiero en cuanto al papel primordial que, considero, debe atribuirse a la imaginación como signo fundamental, como una diferencia específica de lo humano. ${ }^{36}$

${ }^{33}$ Descartes, op. cit., Lettres, Lettre à Elisabeth du 28 juin 1643, p. 1158.

${ }^{34}$ Descartes, op. cit., Cinquièmes Réponses, p. 483.

${ }^{35}$ Esta tesis tiene como fundamento la concepción cartesiana del hombre y del animal, el hombre-máquina, las metáforas del mecanismo de relojería (relación con Huygens) en la perfección del funcionamiento del cuerpo, las diferencias con el animal, sus divergencias con la concepción de Montaigne, todo lo cual evidentemente debe quedar fuera de los márgenes de este ensayo.

${ }^{36}$ M.N. Lapoujade, Filosofia de la Imaginación, cap. 3, V, La imaginación: definición del hombre, pp. 193-215. 
Segundo, respecto de la respuesta a la pregunta: ¿es posible el pensamiento sin imágenes?, apartándome de la concepción cartesiana, asumo que, con base en la experiencia y en largos años de investigación, encuentro extremadamente difícil, si no imposible, recortar el uso puro del entendimiento, sin imágenes, y en general, aislado de recuerdos, perceptos, sentimientos, sensaciones físicas diversas, aunque ellas pasen a un segundo plano, puedan no ser pertinentes, y se tornen un halo de penumbra rodeando un trabajo llamado "puramente" racional. Considero este tipo de trabajo "primordialmente" racional, pero no "puramente" racional. Aun en matemáticas y en geometría, aún el chiliogone emerge de un fondo más o menos confuso e indistinto de imágenes en las que se engarza, ilustra, expresa, valora, resume, adorna, y quizás aun, participan en su constitución.

Las operaciones aritméticas, pongamos por caso, se realizan por razonamientos abstractos; sin embargo, apoyados sobre signos escritos, es decir, imágenes; o bien mentalmente realizadas por medio de signos-imágenes, ahora imaginados, es decir, trasladados a nivel mental como imágenes en el espíritu, de tal modo que constituyen imágenes de imágenes.

El pensamiento sin imágenes, absolutamente abstracto, es algo así 22 como pensar el vacío. El vacío, la ausencia de un referente se presenta imaginariamente en alguna forma. Incluso en el caso de la imaginación en la espiritualidad de Ignacio de Loyola, cuyo papel es esencial, en sus más altos momentos de vivencia de Dios, se desvanecen las imágenes visuales para dar paso a la sonoridad: sonidos imaginarios son el último momento ante la inminencia de la presencia de Dios.

Por mi parte, no he encontrado ningún proceso psíquico, por alternantes que sean las funciones protagónicas, que actúe sólo, puro, aislado, sin tinte valorativo y aséptico del espíritu todo. En el teatro de la mente hay actores centrales y secundarios, siempre los mismos, alternando sus funciones. Nada de lo que allí ocurre aparece aislado del resto, se manifiesta como un tejido viviente. ${ }^{37}$ Las funciones de la imaginación ponen

${ }^{37}$ En tal sentido, en el extremo puede ubicarse la actividad de la meditación budista. En ella, precisamente, se deja el pensar en estado de actividad fluyente, manteniendo en suspenso todo referente mental, o para decirlo con Husserl: todo cogitatum. 
de manifiesto a la vez su unidad y su diversidad. La unidad de la operación, consiste en que ella es la fuerza cuya "materia" son las imágenes, realiza su trabajo con imágenes que ella segrega. La imaginación produce imágenes, que Descartes, en general, llama "figuras" o "cuadros" (tableaux). En Descartes prevalece la noción de imagen como silueta, por así decir, como un diseño mental visible. La diversidad radica en las múltiples y diferentes actividades que la imaginación puede desarrollar con imágenes que o bien recibe, o reproduce o crea, o transmite, o transforma en su configuración, o en ella se transmutan en su naturaleza.

\section{La imaginación y los sentidos}

\section{Los sentidos}

El papel de los sentidos en la filosofía cartesiana reviste una importancia trascendental, es una voz de alerta ante las lecturas distorsionantes de su pensamiento libre, traducidas a un ciego y dogmático racionalismo. ${ }^{38}$ La Dióptrica se abre con la siguiente afirmación: "toda la conducta de nuestra vida depende de nuestros sentidos". 39

En los límites de este ensayo baste con señalar tres aspectos fundamentales. Primero, el impacto de los datos sensoriales en los órganos corporales de los sentidos, constituyen en sentido literal impresiones. En este punto, todos quienes nos acercamos al pensamiento cartesiano caemos, seducidos, en el exquisito pasaje sobre el trozo de cera:

Tomemos por ejemplo un trozo de cera que acaba de ser tomado de la colmena: aún no ha perdido la dulzura de la miel que contiene; todavía retiene algún aroma de las flores de donde fue sacado; su color, su figura, su tamaño son aparentes; es duro, frío; si se toca, si usted lo golpea, se percibe cierto sonido. En fin, todas las cosas que pueden hacernos conocer claramente un cuerpo se reencuentran en éste.

${ }^{38} \mathrm{He}$ estudiado especialmente este problema en Los sistemas de Bacon y Descartes, cuyo subtítulo, De la coincidencia de los opuestos, da una pista de la tesis central.

${ }^{39}$ Descartes, op. cit., La Dioptrique, Discours premier, De la Lumière, p. 180. 
Pero he aquí que, mientras hablo, se le acerca al fuego: aquello que quedaba de sabor se exhala, el olor se desvanece, su color cambia, se pierde su figura, su tamaño aumenta; se vuelve líquido, se calienta, apenas se le puede tocar, y si alguien lo golpea, no devolverá sonido alguno. ${ }^{40}$

Ante todo importa percibir que en este pasaje, con un "estilo admirable" como lo subraya Paul Valéry, Descartes se prodiga en un modelo de belleza de la lengua francesa. ${ }^{41}$

Segundo, haciendo a un lado la seca discusión filosófica clásica de las cualidades primarias y secundarias, y todos los comentarios habituales; ubicados en el contexto de la filosofía de la imaginación, enfatizo muy especialmente otras líneas no tan explotadas de este admirable pasaje, las cuales, sin embargo, revisten una importancia fundamental para la comprensión cabal del pensamiento cartesiano.

\section{Sentidos e imaginación}

Descartes se pregunta de inmediato:

¿La misma cera permanece después de este cambio? [...] Pero, ¿qué es, hablando propiamente, lo que imagino, cuando yo la concibo de esta forma? [...] Apartando todas las cosas que no pertenecen a la cera, veamos lo que resta. Ciertamente, no permanece nada, salvo cierta cosa de extensión, flexible, mudable. ${ }^{42}$

Este pasaje toca un tema central en Descartes: la relación entre imaginación y extensión. En la Regla XIV, entre otros lugares, reflexiona sobre el tema. Allí precisa que la extensión de los cuerpos se representa a la imaginación por figuras. ${ }^{43}$

Por extensión entendemos todo aquello que tiene longitud, anchura y profundidad [...] No hay necesidad, parece, de mayor explicación de

${ }^{40}$ Descartes, op. cit., Méditations, Méditation Seconde, pp. 279-80.

${ }^{41}$ Paul Valéry, op. cit., Une vue de Descartes, Études philosophiques, Variété, pp. 826-7.

${ }^{42}$ Descartes, idem, p. 280. Las itálicas son propias.

${ }^{43}$ Descartes, op. cit., Règles pour la direction de l'esprit, Règle XIV, p. 97. 
esta extensión, porque no hay nada que nuestra imaginación perciba más fácilmente. ${ }^{44}$

Así pues, la imaginación, función del espíritu, tiende el puente entre la sustancia pensante y la sustancia extensa; sus complejas y generalmente presentes actividades fungen como una suerte de vasos comunicantes entre las dos sustancias que componen el mundo cartesiano: pensamiento y extensión.

De ello puede inferirse una consecuencia igualmente crucial. En Espacios imaginarios, he señalado que la extensión espacial real de los cuerpos, se transmuta en extensión espacial imaginaria, la cual, sostengo, es indudablemente también, aunque de otro modo, real.

Es decir, en ese contexto hemos sostenido la realidad de lo imaginario. ${ }^{45}$ El pensamiento de Descartes en este punto es extremadamente sutil. Ante todo, según nuestro autor, la imaginación hunde su actividad en la realidad de los cuerpos para emplazarla a nivel imaginario, siendo éste el ámbito en que la realidad es rescatada como tal. En este preciso sentido "podemos y debemos servirnos del socorro de la imaginación", la cual debe producir una imagen verdadera de la cosa. ${ }^{46}$

Después, es preciso acompañar a Descartes y dar un paso más. En este segundo momento, su pensamiento se profundiza y se vuelve completamente contemporáneo. Muestra que la diferencia entre real e imaginario es irrelevante en casos decisivos; entre ellos, en la geometría. Es preciso recuperar unos pasajes en que este enunciado radicalmente sutil, riguroso y actual es explícito. En la Regla XIV se explica:

En efecto, es algo real la gravedad del cuerpo, la rapidez del movimiento o la división del siglo en años y días; pero no es algo real la división del día en horas y en minutos, etc. Y, sin embargo, todas estas cosas son equivalentes si se les considera sólo con respecto a la dimensión, como se

${ }^{44}$ Idem.

${ }^{45}$ M.N. Lapoujade, Espacios imaginarios (Compiladora), Primer coloquio internacional de Estética, México, Universidad Nacional Autónoma de México, 1999, Prólogo, pp. 7-13; Palabras de apertura, pp. 15-18.

${ }^{46}$ Descartes, op. cit., Règles, Règle XIV, p. 100. 
debe hacer aquí en las ciencias matemáticas, pues pertenece más bien a los físicos examinar si el fundamento es real.

Esta consideración aproxima un gran día para la geometría $[\ldots]$ Hace falta enfatizar, de pasada, que las tres dimensiones de un cuerpo, longitud, anchura, y profundidad, no difieren ente ellas más que por el nombre, puesto que nada impide que, en un sólido dado, no se elija la extensión que se quiera como la longitud, otra como anchura, etc. Y aunque estas tres dimensiones tuviesen sólo un fundamento real en toda cosa con extensión, en tanto que simplemente extensión, nosotros no las tomamos en consideración mayor que un infinito de otras cosas, que son imaginadas por el entendimiento o que son fundamento de otras cosas. ${ }^{47}$

Por mi parte, generalizando esta tesis, para asumirla como perspectiva filosófica central, la que he desarrollado larga y cuidadosamente en La imaginación estética en la mirada de Vermeer, considero que la geometría en general es un ámbito imaginario. La imaginación rige su construcción. ${ }^{48}$

En lo que respecta a las figuras, Descartes considera que es por ellas que es posible formar las ideas de todas las cosas. Por su parte, en la Regla XV, Descartes muestra con ejemplos de figuras en su texto cómo las imágenes producidas por la imaginación permiten trazar las figuras. ${ }^{49}$

26 La Regla XVI es un breviario del papel de la imaginación en la geometría cartesiana. El uso de la imaginación permite la simplificación de los trabajos de la geometría sustituyendo la construcción imaginaria de las figuras completas por signos muy cortos, para así ayudar a la memoria. Se trata de "introducir signos que se pueden imaginar como se quiera". Descartes en su geometría utiliza letras a,b,c para extensiones conocidas y A,B,C para las desconocidas. En síntesis, la geometría entera se despliega ante la imaginación para que ella guíe sus trabajos. ${ }^{50}$

En La Dióptrica, la imaginación continúa con su papel rector, ya sea en la concepción cartesiana de la luz, como en los temas centrales inherentes a ella: los procesos de refracción y de reflexión.

${ }^{47}$ Descartes, idem, p. 103.

${ }^{48}$ M.N. Lapoujade, La imaginación estética en la mirada de Vermeer, México, Editorial Herder, 2006, Segunda Parte, Pintura y Geometría, pp. 91-125.

${ }^{49}$ Descartes, op. cit., Règles..., Règle V, p. 106.

${ }^{50}$ Idem, Règle XVI, pp. 107-11. 
Al respecto, me remito a La imaginación estética en la mirada de Vermeer, donde he desarrollado detenidamente el papel de la imaginación en la óptica, así como la concepción cartesiana de la luz, en relación con Huygens, y contemporáneamente, con Einstein. ${ }^{51}$

Tercero, para continuar con el último de los aspectos a considerar en lo que respecta al tema de los sentidos y la imaginación en el pensamiento de Descartes, es preciso subrayar que las impresiones son recibidas por los órganos corporales de los sentidos, es decir, son recibidas en el cuerpo. Así, el tema de las sensaciones y las imágenes que les son inherentes pone de manifiesto otro aspecto medular de la imaginación humana.

\section{La imaginación y el cuerpo}

En primer lugar, estamos ante un problema de una extrema complejidad en el pensamiento cartesiano. En segundo, por si esto fuera poco, se trata de un tema que forma parte de una temática que considero aporética en el pensamiento cartesiano: las relaciones alma-cuerpo. ${ }^{52}$

Maurice Merleau-Ponty desarrolla el tema en profundidad. En su magistral estudio sobre El ojo y el espíritu, las referencias a Descartes son fundamentales porque muestra que la relación entre alma y cuerpo en el pensamiento cartesiano es vivida como una intensa intimidad. De acuerdo con Descartes, para el alma:

es lugar del cuerpo que llama "suyo", es un lugar que ella habita. El cuerpo que ella anima no es, para ella, un objeto entre objetos [...] El cuerpo es para el alma su espacio natal y la matriz de todo espacio existente. ${ }^{53}$

En tercer lugar y última instancia, creo que la expresión "aporética" resulta muy pobre, pues se trata de un asunto mucho más radical, es una cuestión en la cual la especie humana alcanza el límite del misterio.

${ }^{51}$ M.N.Lapoujade, La imaginación estética en la mirada de Vermeer, Segunda Parte, La pintura y la luz: en la frontera entre la geometría y la óptica, pp. 129-35.

${ }^{52}$ M.N. Lapoujade, Filosofía de la imaginación, cap. 1, Diacronía, pp. 53-4.

${ }^{53}$ Maurice Merleau-Ponty, L'oeil et l'esprit, 1964, Paris, Gallimard, Folio-Essais, III, pp. 53-4. 
Ni la filosofía cartesiana ni ninguna otra antes o después ha encontrado la solución de este enigma. Vivimos envueltos en el misterio y el misterio anida también en el fondo último de la intimidad.$^{54}$ Los sentidos, funciones del cuerpo, operan como receptores de los impactos de los objetos exteriores, tal como la cera recibe la figura de un sello. Descartes precisa que no se trata de una analogía, sino que son procesos de la misma índole: el cuerpo que siente es modificado por el objeto. Se trata de un proceso primeramente fisiológico:

Lo mismo para los otros sentidos: la primera parte opaca del ojo recibe así la figura que imprime en ella la luz coloreada de distinta manera, y la primera membrana de las orejas, nariz y lengua, impenetrable al objeto, recibe también una nueva especie de sonido, de olor y de sabor. ${ }^{55}$

Las impresiones sensoriales son figuras, es decir, imágenes. ${ }^{56}$ Las imágenes son transportadas a otra parte del cuerpo llamado "sentido común”, función del cerebro, concretamente la glándula pineal (hipófisis). El cerebro, a través de la glándula pineal (la hipófisis) toma el relevo e imprime la imagen en la imaginación corporal, de modo que se produce una transmisión corpórea de la imagen. ${ }^{57}$

En nuestro siglo, Paul Chauchard despliega desde la neurofisiología actual lo que la genialidad de Descartes concibió claramente avant la lettre. Chauchard subraya el papel crucial de la relación imaginación-cerebro. Me limito a citar unas líneas de suma pertinencia:

Lo imaginario, al ser imagen cerebral, tiene la existencia activa de un proceso psicoquímico cerebral que transtorna el funcionamiento cerebral y, por los centros de la base, todo el equilibrio visceral.

${ }^{54}$ M.N. Lapoujade, El misterio construido, julio 1994, San José, Costa Rica, Revista de la Universidad de Costa Rica. vol. XXXII. núm. 77, pp. 103-7, y/o El misterio construido, Relaciones, núm. 125, octubre 1994, Montevideo, pp. 9-10.

${ }^{55}$ Idem, p. 76.

${ }^{56}$ Obviamente no es posible desarrollar aquí este aspecto del tema.

${ }^{57}$ Para el análisis de las relaciones de la imagen y el cerebro, es imprescindible revisar los aportes de la neurofisiología actual. En particular, señalo la importancia de las investigaciones de Paul Chauchard, entre las que una muestra muy significativa se encuentra en su ensayo "La realización corporal de la persona", incluido en El zen y el cerebro, de Taisen Deshimaru y Paul Chauchard, Barcelona, Editorial Kairos, 2001. Cfr. especialmente cap. VI, "La sabia imaginación de lo verdadero". 
¿Eliminar lo imaginario? Imposible. Y si tratamos de hacerlo, se crea una incoercible necesidad de imaginación.

Después de una explicación precisa, concluye:

Por lo tanto, cualquier actividad cerebral es una imaginación, lo que cambia totalmente nuestra perspectiva sobre esta función. En nuestro cerebro brota sin cesar un torrente de imágenes en la intuición y es la riqueza de esta imaginación la que da valor no solamente al artista, sino también al científico. ${ }^{58}$

Sin embargo, en lo más sutil de este proceso, en algún momento la imagen corporal y cerebral deviene imagen mental, espiritual, transmutación del cuerpo en alma, del cerebro en espíritu, que sigue siendo aún hoy tan aporético como en la época de Descartes y su sistema. De acuerdo, una vez más con Paul Valéry, concluyo:

El problema permanece, establecido con mucho mayor precisión, pero permanece al fin. En cuanto a las relaciones del organismo con los "hechos de conciencia" o con la sensibilidad subjetiva, nada nuevo desde $1650 . .^{59}$

Concluimos la teoría de la imaginación en Descartes, con un pasaje delicioso, en el que nuestro filósofo, cansado de la prudencia, nos muestra su espíritu mordaz y el sarcasmo lúcido de su humor:

Lo que he dicho acerca de la imaginación es muy claro si se mira y se toma conciencia, pero no es una maravilla si parece confundir a aquellos que no meditan jamás y que no hacen alguna reflexión sobre lo que piensan. ${ }^{60}$

Para su genio, la imaginación no solamente es una teoría inserta en su sistema teórico total, sino que, además, la imaginación vivida es medular al Descartes hombre y se derrama en la intimidad de su filosofía autobiográfica inaudita.

\footnotetext{
${ }^{58}$ Paul Chauchard, op. cit., pp. 146-7.

${ }^{59}$ Paul Valéry, op. cit., Une vue de Descartes, Problèmes Philosophiques, Variété, p. 833.

${ }^{60}$ Descartes, op. cit., Cinquièmes Réponses, p. 483.
} 


\section{La imaginación vivida}

\section{La imaginación diurna en Descartes}

Evocamos un pasaje autobiográfico, extraído de una carta a Elisabeth del 28 de junio de 1643.

Y puedo decir, con verdad, que la principal regla que he observado siempre en mis estudios, y la que creo que me ha servido más para adquirir algún conocimiento, ha sido que no he empleado jamás más que un par de horas, por día, a los pensamientos que ocupan la imaginación, y pocas horas más, por año, a aquellos que ocupan sólo al entendimiento, y que he utilizado el resto de mi tiempo al relajamiento de los sentidos y al reposo del espíritu; así mismo, cuento, entre los ejercicios de la imaginación, a todas las conversaciones serias y a todo lo que demanda atención. Es lo que ha hecho que me retire al campo. ${ }^{61}$

Este pasaje contiene datos preciosos. Ante todo, hablar de autobiografía en Descartes son palabras mayores. Obsérvese el papel central de la imaginación en su vida de sabio, en la búsqueda del conocimiento. La importancia del descanso de los sentidos y el reposo del espíritu. Descanso y reposo. El retiro a los campos, eso habla de la necesidad del silencio y de la soledad. Por ahora retengamos estos cuatro datos.

\section{La imaginación nocturna}

La determinación completa del ser humano exige observar, además, los trabajos nocturnos de la imaginación y, por desconcertante que pueda parecer, el lado de la imaginación nocturna fue decisiva en el Descartes pensador. En este instante de nuestra reflexión es preciso aguzar el oído porque la revelación súbita de la ciencia universal, la necesidad del método para alcanzar la Verdad, el sí y el no, y en última instancia, el trofeo del cogito allí escondido aún, se hace patente a Descartes

${ }^{61}$ Descartes, op. cit., Lettre à Elisabeth, Egmond-du-Hoef, 28 juin 1643, p. 1159. 
durante la noche del 10 al 11 de noviembre de 1619 en tres sueños. Los sueños:

No obstante, debo considerar aquí que soy hombre y, por consecuencia, acostumbro dormir y representarme en mis sueños las mismas cosas, o algunas veces menos verosímiles, que aquellas insensatas, cuando velan.

Me parece bien, en el presente, no mirar este papel con ojos somnolientos; que es con designio y propósito deliberado que extiendo esta mano, y que la siento: lo que llega en el sueño no parece más claro ni distinto que los demás. Pero al pensar cuidadosamente, vuelvo a recordar haberme equivocado de pronto, mientras dormía, por ilusiones semejantes y, deteniéndome en este pensamiento, veo de manera manifiesta que no existen indicios concluyentes, ni marcas lo suficientemente ciertas por donde sea posible distinguir netamente la vigilia del sueño, que estoy por completo atónito. $^{62}$

En la oscuridad de la noche irrumpe la luz diurna del camino de la verdad.

Las imágenes oníricas le sitúan ante su primera evidencia, es decir, esa visión que se impone a su espíritu con absoluta necesidad. De esta manera, puede afirmarse que la imaginación cartesiana de vigilia culmina en la imaginación onírica, es decir, en la inmediatez de las imágenes: inconsciente y dormido recibe la "revelación" de la verdad filosófica central.

\section{La imaginación poética}

Descartes, el prudente hombre de mundo, el viajero infatigable, el humanista a quien "nada de lo humano le es ajeno" (Terencio), en su juventud plasma en sus Cogitationes privatae esa certidumbre reveladora.

De la misma manera que la imaginación se sirve de figuras para representarse los cuerpos, así el entendimiento se sirve de cuerpos que caen sobre nuestros sentidos para figurar las cosas espirituales, como el viento y la

${ }^{62}$ Descartes, Méditations, Première Méditation, pp. 268, 269. 
luz: de lo que se sigue que, practicando una filosofía más noble, podemos, por el conocimiento, llevar nuestro espíritu hacia las alturas. Podría asombrar que los pensamientos profundos se encuentren en los escritos de los poetas más que en los de los filósofos. La razón es que los poetas escriben por medio del entusiasmo y de la fuerza de la imaginación: hay en nosotros semillas de ciencia, como en el sílex, que los filósofos tiran de día por medio de la razón y que los poetas, por medio de la imaginación, hacen brotar y brillar mejor. ${ }^{63}$

\section{Criterio metafórico de verdad}

Visión y evidencia, acto de la mirada indubitable, requieren de lo visto. Y lo visto son formas, configuraciones, lo cual es otra manera de decir imágenes. Su criterio visual de verdad, es lo claro y lo distinto, lo cual es una evidencia, es decir, un acto de ver.

La aprehensión se da en una intuición, palabra que significa un movimiento inmediato de visión. ${ }^{64}$ ¿De ver qué? Visión de la verdad apodíctica de la luz, óptica y metáfora capital en el sistema cartesiano, eco de esa metáfora crucial en historia de la humanidad.

\section{Transgresión del cogito}

Descartes, erguido sobre la roca del cogito, alcanza a vislumbrar que el ensimismamiento del cogito del hombre de vigilia, despierto, racional, sano, consciente y culto no basta para bañar de luz a la humanidad. Así, en su autobiografía intelectual llamada Discurso del método leemos:

Pero tan pronto hube adquirido nociones generales de física y comenzando a ponerlas a prueba en varias dificultades particulares, noté cuán lejos pueden llevarnos y cuán diferentes son los principios que se han usado

${ }^{63}$ Descartes, Cogitationes privatae, citado por Samuel S de Sacy, op. cit., p. 69.

${ }^{64} \mathrm{He}$ enfocado este tema en El ojo y el oído o una historia estética de la filosofia, agosto 1990, México, Revista Plural Excélsior, núm. 227, pp. 27-32. Id., Montevideo, Revista Graffiti, año 4, núm. 30, Junio 1993, pp. 16-22. 
hasta ahora; creí que conservarlas ocultas era grandísimo pecado, que infringía la ley que nos obliga a procurar el bien general de todos los hombres, en cuanto esté en nuestro poder. Pues esas nociones me han enseñado que es posible llegar a conocimientos muy útiles para la vida y que, en lugar de la filosofía especulativa, enseñada en las escuelas, es posible encontrar una práctica, por medio de la cual, conociendo la fuerza y las acciones del fuego, del agua, del aire, de los astros, de los cielos y de todos los demás cuerpos que nos rodean, tan distintamente como conocemos los oficios varios de nuestros artesanos, podríamos aprovecharlas del mismo modo, en todos los usos a los que sean propias y, de esa suerte hacernos como dueños y poseedores de la naturaleza. ${ }^{65}$

De esta manera, Bacon y Descartes se reencuentran, una vez más, con pasajes exactamente simétricos. Este pasaje es altamente significativo del encuentro de dos espíritus en el punto de partida de sus sistemas, en la subjetividad purificada de errores, prejuicios, etc., y en una generosa finalidad, porque sus miras están puestas en el mejoramiento de la humanidad toda.

\section{Conclusión}

Gaston Bachelard afirma sabiamente:

La filosofía tradicional se ocupa comúnmente del hombre que piensa, como si el hombre encontrara toda su substancia, todo su ser en el pensamiento [...] La filosofía olvida muy seguido que, antes del pensamiento, está el sueño, que antes de las ideas claras y estables están las imágenes que brillan y que pasan. Tomado en su integralidad, el hombre es un ser que no solamente piensa, sino que en principio imagina; un ser que, despierto, es asaltado por un mundo de imágenes precisas y que, dormido, sueña dentro de una penumbra donde se mueven formas inacabadas, formas que se desplazan sin leyes, formas que se deforman $\sin$ fin. ${ }^{66}$

${ }^{65}$ René Descartes, Discours de la Méthode, 1961, Paris, Vrin, Sexta Parte, pp. 121-22.

${ }^{66}$ Gaston Bachelard, Causeries, 2005, Genova, Editorial Il melangolo, Edición bilingüe, p. 90. 
Y, precisamente, nuestra reflexión nos lleva a concluir que Descartes se sale de la filosofía tradicional para encarnar este modelo del filósofo contemporáneo. La filosofía de Descartes nace del filósofo que ha sabido escuchar su voz interior. Escuchar su voz interior le ha llevado a habitar la escucha del silencio musical de los campos; a vivir el silencio de la soledad atenta; a recoger los frutos de la lentitud del reposo. Allí en la libertad íntima de ese cielo sereno irrumpe con la fuerza del relámpago la experiencia radical, la intuición del cogito que se vive con la intensidad inusitada del instante.

Es el acto repentino de ver la luz que brota en un instante.

En ese mismo rincón luminoso del espíritu, Descartes maduro, encuentra que ese minúsculo ser instantáneo de luz transgrede su propio límite, deja su ensimismamiento y sale de sí. En ese mismo rincón luminoso del espíritu el hombre se descubre en su hábitat natural, en el paisaje que lo constituye. Y así, entre los cuatro elementos, fuego, agua, aire, tierra, entre los astros y los cielos, llega a ser el que es: un ser cósmico. 